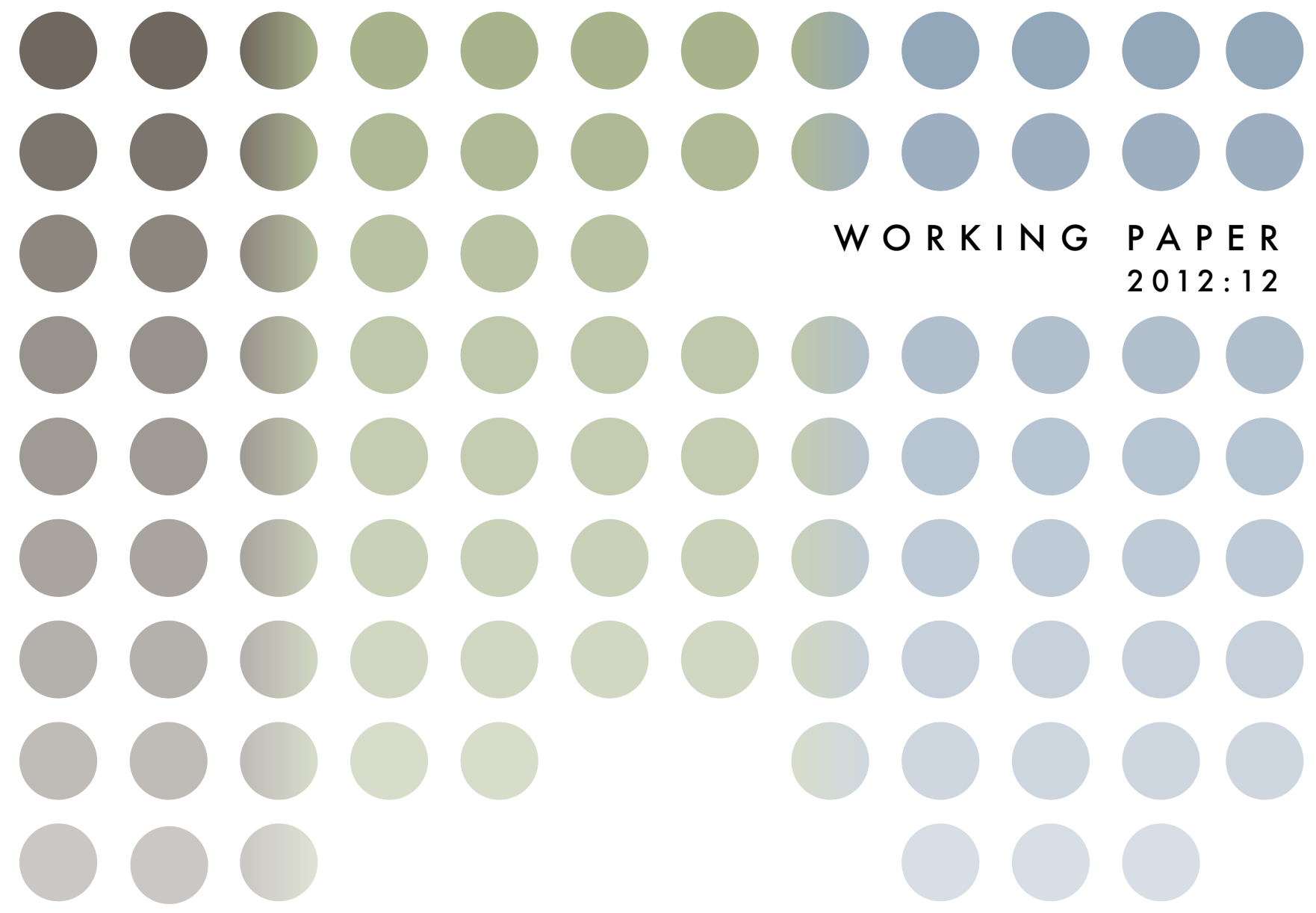

\title{
Property Rights and the Cost of Capital
}

\author{
Per-Olof Bjuggren och Johan Eklund
}




\section{Working Papers Series from Swedish Entrepreneurship Forum}

In 2009 Swedish Entrepreneurship Forum started publishing a new series of Working Papers. These are available for download on www.entreprenorskapsforum.se, and are part of our ambition to make quality research available to a wider audience, not only within the academic world.

Scholars from different disciplines are invited to publish academic work with the common denominator that the work has policy relevance within the field of entrepreneurship, innovation and SMEs.

The working papers published in this series have all been discussed at academic seminars at the research institution of the author.

\section{ABOUT SWEDISH ENTREPRENEURSHIP FORUM}

Swedish Entrepreneurship Forum is the leading Swedish network organization for generating and transferring policy relevant research in the field of entrepreneurship and small enterprise development.

Swedish Entrepreneurship Forum is a network organization with the aim

- to serve as a bridge between the small business research community and all agents active in development of new and small enterprises.

- to initiate and disseminate research relevant to policy in the fields of entrepreneurship, innovation and SME.

- to offer entrepreneurship researchers a forum for idea sharing, to build national and international networks in the field and to bridge the gap between research and practical application.

Find out more on www.entreprenorskapsforum.se 


\title{
Property Rights and the Cost of Capital
}

\author{
2012
}

Per-Olof Bjuggren ${ }^{1}$ och Johan Eklund ${ }^{2}$

\begin{abstract}
In countries with more secure property rights, the cost of capital is lower, suggesting higher investment rates. Using data from 49 countries we extend the conventional capital-asset pricing model (CAPM) to include a property rights risk-factor. In the conventional CAPM model only a single risk factor - systemic risk - is considered. However, when using a world market portfolio to estimate systemic risk in national portfolios, little of the required rate of return is explained in less developed as compared to more developed countries. Adding a factor representing institutional risk increases predictive power substantially. Further, we find that property rights affect the transmission of information, which suggests that markets price information differently, and allocate resources less efficiently, in countries with less secure property rights. We find that the CAPM model performs better in countries with more secure property rights.

Keywords: Asset pricing $\cdot$ International financial markets $\cdot$ Property rights $\cdot$ Cost of capital $\cdot$ Investment.

JEL: G12 $\cdot$ G15 $\cdot$ G38 $\cdot$ N20.
\end{abstract}

\footnotetext{
${ }^{1}$ Professor of Economics,Jönköping International Business School and Ratio Institute P.O. Box 3203, SE-103 64 Stockholm, Sweden, Tel: +46 76087 12, Fax: +468 4415929, E-mail: p-o.bjuggren@ratio.se

2 Associate Professor of Economics, Jönköping International Business School and Entrepreneurship Forum, P.0. Box 1026, SE55111 Jönköping, Sweden
} 


\section{Institutional risk, property rights and required return}

In the required rate of return on investment, a premium for institutional risk should be included, varying by country, covering the "rules of the game" facing investors. The origin of legal systems and the strength of investor protection determine the size of capital markets (La Porta et al. 1997) and investment performance (Gugler et al. 2004).

Rules can be supportive or make long-term investments hazardous due to lack of secure property rights. In countries with more secure property rights, firms allocate resources better and grow faster (Claessens and Laeven 2003), while insecure property rights discourage investors from reinvesting profits (Johnson et al. 2002). Thus property rights affect economic growth (Barrow 1991). Insecure property rights can be why systemic risk to a larger extent determines rate of return on stock in less developed than in more developed countries (Morck et al. 2000). Secure property rights are important for keeping transaction costs low (Coase 1960; Demsetz 1964; Alchian and Demsetz 1972), so investors must use a higher discount rate in evaluating investments when property rights are insecure.

Though the concept of "political risk" is sometimes mentioned exactly, how institutional risk affects investors has not received much attention in the financial economics literature, and formal treatment has not been offered. With few exceptions, the mechanisms through which weak institutions in general, and insecure property rights in particular, influence capital markets have largely been overlooked.

The purpose of this paper is to show the existence of institutional risk premiums related to property rights protection and to measure their magnitude in countries where property rights protection differs.

We take a global perspective in studying how the rate of return on national portfolios can be explained by co-movement with a world portfolio. We find that the capital asset pricing model (CAPM) provides a better fit for countries with more secure property rights. The world portfolio explains more of the rate of return of national portfolios the more developed the countries are. Confirming Morck et al. (2000), we find that the security of property rights is an important factor in analyzing the required rate of return on stocks in both more or less developed countries.

We estimate the size of the "property-rights risk premium" across countries. It turns out that the level of property rights protection is a systemic risk that is priced in national stock exchanges. Therefore, to understand the required rate of return across countries one must add property rights risk to conventional market-risk (market-index).

Section 2 discusses what is meant by institutional risk related to property rights and how this affects the cost of capital, while Section 3 discusses how to calculate capital costs and risk premiums for assets with such risk. The data used in our empirical analysis is presented in Section 4, the empirical findings in section 5. Section 6 draws conclusions. 


\section{Property rights and the cost of capital}

Investments are risky: A cost in the form of a capital outlay is paid today, while the benefits of positive cashflows will be received in the future. An investment is therefore a deferred exchange where a payment is made today in return for uncertain enhanced future consumption. When the future unfolds, it might happen that the products produced by the new capital (the investment) cannot be sold profitably.

This is a risk that every entrepreneur has to face. But in addition to this, as discussed above, there might be institutional risk caused by insecure property rights, including a defective judicial system making it difficult to enforce contracts in an effective way. The importance of secure property rights, including reliable contract enforcement, was discussed already by David Hume and Adam Smith as a cornerstone for efficient market transactions and the prosperity of a nation. ${ }^{3}$

Hence, a primary economic task of the state is to provide secure property rights, freedom of contracts and enforcement of agreements through a well-functioning institutional framework of formal rules "include[ing] political (and judicial) rules, economic rules, and contracts" (North 1990, p. 47). Such a set of rules (institution) is according to North property rights, defined as "(...) the bundle of rights over the use and the income to be derived from property and the ability to alienate an asset or a resource" (p. 47). The links to investment are clear, as investment means the creation of new assets. Further, North asserts a hierarchical order among rules which: "(...) descend from polities to property rights to individual contracts" (p. 52). These institutions are thought to be very stable over time (North 1981; North 1990; Williamson 2000).

The explanation for the varying degree to which countries succeed in capital formation and accumulation may be found in these institutions. Hernando de Soto (2000) writes: "When advanced nations pulled together all the information and rules about their known assets and established property systems that tracked their economic evolution, they gathered into one order the whole institutional process that underpins the creation of capital. If capitalism had a mind, it would be located in the legal property system" (p. 65).

In other words it is through secure property rights, free transfer, and contract enforcement that a nation can stimulate investments and growth., or not. The institutional framework might reassure investors that no one else will appropriate the fruits of their investment or it might make investors believe that there is a risk that someone else will reap the benefits. If the latter, long-term investments will be hampered and welfare lower.

If investors cannot rely on reaping the benefits of their investments, they will ipso facto require a higher return in order to supply capital, which will raise the cost of capital for firms and entrepreneurs.

\footnotetext{
${ }^{3}$ They stressed the importance of “(...) the guarantee of property rights, the free transfer of property by voluntary contractual agreement, and the keeping of promises made" (Kasper and Streit 1998, p 20).
} 


\section{Risk, return, and portfolio theory}

Conventional investment theory holds that investors evaluate alternative investments based on their net present value (NPV), the present value (PV) of expected cash-flows (CF) minus the initial investment (I), (NPV $=P V-I)$. Only projects with positive net present value should be initiated. When calculating $P V$ one uses a discount factor, $1 /(1+r)$, where $r$ is the discount rate, also referred to as the required rate of return or as the cost of capital. The discount rate depends on the riskiness of future cash-flows. For risk-free projects the required rate of return equals the risk-free interest rate, which also serves as a reference when valuing risky assets.

The present value of expected cash-flows is calculated as

$$
P V=\sum_{t=1}^{T} \frac{C F_{t}}{(1+r)^{t}}
$$

With riskier cash-flows the discount rate will be higher. As the discount rate increases, present value declines, and the aggregate number of investments declines, since some now appear unprofitable.

The crucial question is therefore how to determine the discount rate based on the risk associated with possible investments. We argue that the discount rate can be broken down into a multitude of components, among which property-rights protection is one. Accordingly the present value formula should be

$$
P V=\sum_{t=1}^{T} \frac{C F_{t}}{\left(1+r_{f}+R P_{p}+R P_{o}\right)^{t}}
$$

where $r_{f}$ is the risk-free interest rate as before; $R P_{p}$ the risk-premium associated with property rights protection; and $R P_{o}$ a "general" market risk-premium. ${ }^{4}$

The conventional Capital Asset Pricing Model makes a distinction between diversifiable firm specific risk and non-diversifiable systemic risk. Because, on a global capital market specific risk can be diversified away, only the remaining non-diversifiable risk matters for the pricing of the asset; i.e., investors are only compensated for non-diversifiable systemic risk.

As a consequence, the return $(r)$ that investors require depends on the systemic risk related to the investment (see next section). But the institutional risk related to property rights and contract-enforcement is associated with the framework of rules of a country, both informal rules such as norms and customs based on tradition and religion, and formal such as property and contract laws and their enforcement. It is primarily the formal rules that a polity can exert an influence upon, since informal rules change only very slowly (North 1990; Williamson 2000). Even formal change in property rights rules and their enforcement tend to take decades to implement. So an investor is stuck with the institutional framework for a considerable time.

\footnotetext{
${ }^{4}$ A political risk-premium is proposed by Faure and Skogh (2003).
} 
Prospects for diversifying risk by balancing changes in the security of property rights through an international portfolio are small. (If changes to property right regimes were frequent global investors could include both positive and negative changes in the quality of property rights protection. However, given the stability of institutions over time this is not possible in practice.) Hence, the possible insecurity of property rights is a truly systemic risk that, according to theory (see next section), increases the required return on investment, raising the cost of capital will, and further decrease investment.

According to CAPM, the expected return on a security can be calculated as

$$
E\left(r_{i}\right)=r_{f}+\beta_{i}\left(E\left(r_{m}\right)-r_{f}\right)
$$

where $\beta_{i}$ measures the sensitivity of a security to market (systemic) risk; and $r_{m}$ is the return on a market portfolio, $m$. The model thus holds that the expected rate of return equals the risk-free interest rate plus a risk premium that varies with $\beta$. This expected rate of return is the discount rate $r$ used in Equation 1 to calculate the present value of future cash-flows. The term $E\left(r_{m}\right)-r_{f}$ is the market price of risk for efficient portfolios. In this model it is only this one factor, the market portfolio, that matters in calculating the risk premium.

This standard CAPM can be extended into the so-called multi-beta CAPM by including other factors that influence the size of the risk premium (Merton 1973). Following this approach, we add uncertainty about property rights as a risk factor.

Theoretically or ideally, all assets in the entire world should be included in the market portfolio $m$ (Roll 1977). However, in the empirical literature, national stock-indices such as Standard and Poor 500 and the New York Stock Exchange index are usually used. More "correct" would be use an index containing all securities in the entire world, such the Morgan Stanley world-market index, and that is what was used as the market portfolio in the present study.

Estimation of $\beta$ and the risk premium can be done according to a two-pass procedure. ${ }^{5}$

Several studies of CAPM using the two-pass procedure suggest that a two-factor model (a multi-CAPM) should be used (Sharpe and Cooper 1972; Douglas 1968; Black et al. 1972). So there is some empirical support for use of a model where both property rights and the market portfolio are included as factors in calculating the cost of capital. Our second-pass regression thus contains a second factor representing institutional risk and looks like

$$
\bar{r}_{i}=\alpha_{i}+R P_{m} \times \hat{\beta}_{i}+R P_{p} \times \text { Institutional Risk }+\varepsilon_{i}
$$

where $R P_{p}$ represents risk of insecure property rights.

\footnotetext{
${ }^{5}$ See e.g. Elton and Gruber (1996)
} 


\section{Variables, data and $\mathrm{R}^{2}$ around the world}

To calculate the impact of institutional risk on the risk premium and the required return on investments stock-exchange data, data about the level of property rights protection, and world market-portfolio are needed. Table 1 shows the data we used.

Table 1 - Description of variables

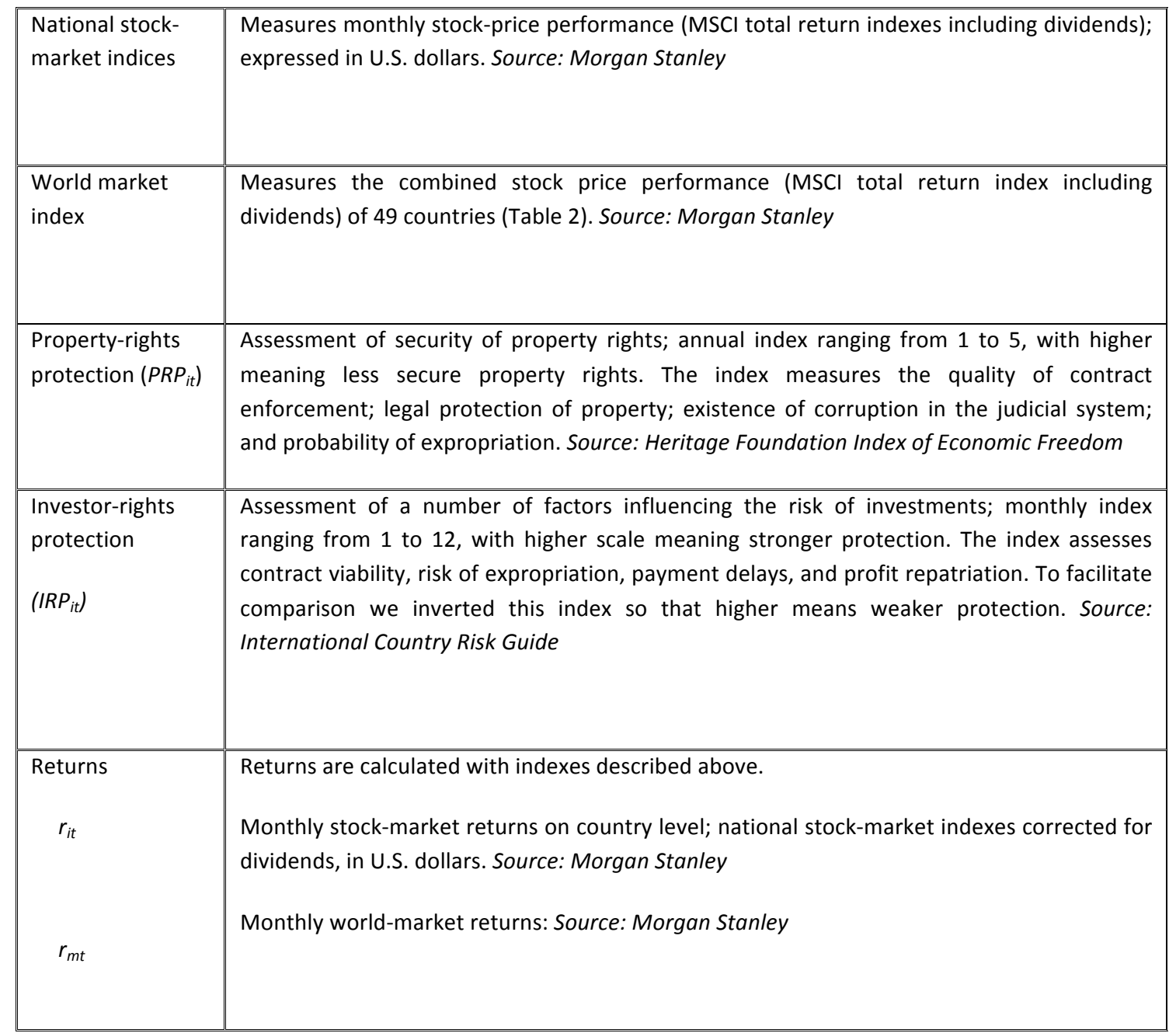

Monthly stock-market indexes compiled by Morgan Stanley were used to calculate the rate of return on national stock markets, for 1995 to 2005 (129 months more exactly), expressed in U.S. dollars and including dividends. Thus the indices are consistently defined and include all relevant returns. As a proxy for the market portfolio the world stock-market index from Morgan Stanley was used, covering 49 more or less developed countries indexes (Table 2, below).

As indicated, two measures of institutional risk were used, for property rights and investors rights; the availability of these indices for all 49 countries determines the study period. 
Estimation was divided into two steps: 1) estimating a standard CAPM for each country in our sample, for this we obtain estimated beta-values for each; 2) calculating the average return for each country, running a cross-country analysis, and adding measures of property-rights and investor rights protection.

After performing the first step, we have country data showing the rate of return, the sensitivity of rate of return to changes in the world market portfolio $\left(\beta_{i}\right)$, property rights risk according to two indices, and $\mathrm{R}^{2}$ values showing how much of the national rate of return can be explained by the world rate of return (Table 2).

Table 2 Country data for 1995-2005 (129 months)

\begin{tabular}{|c|c|c|c|c|c|}
\hline More & $\hat{\beta}$. & $R^{2}-$ values & Property & Investor right & Average rate \\
\hline Australia & 0.87 & 0.53 & 1.00 & 1.60 & 0.128 \\
\hline Austria & 0.61 & 0.22 & 1.00 & 1.31 & 0.122 \\
\hline Belgium & 0.80 & 0.40 & 1.00 & 1.38 & 0.127 \\
\hline Canada & 1.11 & 0.68 & 1.00 & 1.41 & 0.160 \\
\hline Denmark & 0.84 & 0.47 & 1.00 & 1.46 & 0.150 \\
\hline Finland & 1.62 & 0.40 & 1.00 & 1.37 & 0.221 \\
\hline France & 1.07 & 0.69 & 2.00 & 1.42 & 0.125 \\
\hline Germany & 1.26 & 0.65 & 1.00 & 1.41 & 0.105 \\
\hline Greece & 0.95 & 0.20 & 2.36 & 1.74 & 0.164 \\
\hline Hong Kong & 1.20 & 0.38 & 1.00 & 1.57 & 0.108 \\
\hline Ireland & 0.85 & 0.48 & 1.00 & 1.35 & 0.107 \\
\hline Italy & 0.94 & 0.39 & 2.00 & 1.50 & 0.131 \\
\hline Japan & 0.87 & 0.37 & 1.36 & 1.41 & 0.011 \\
\hline Netherlands & 1.08 & 0.68 & 1.00 & 1.34 & 0.106 \\
\hline New Zealand & 0.81 & 0.30 & 1.00 & 1.42 & 0.106 \\
\hline Norway & 1.07 & 0.48 & 1.18 & 1.46 & 0.140 \\
\hline Portugal & 0.82 & 0.32 & 2.00 & 1.52 & 0.107 \\
\hline Singapore & 1.15 & 0.37 & 1.00 & 1.36 & 0.045 \\
\hline Spain & 1.14 & 0.59 & 2.27 & 1.34 & 0.178 \\
\hline Sweden & 1.42 & 0.60 & 1.64 & 1.48 & 0.172 \\
\hline Switzerland & 0.79 & 0.45 & 1.27 & 1.34 & 0.124 \\
\hline United Kingdom & 0.77 & 0.69 & 1.00 & 1.36 & 0.103 \\
\hline United States & 1.00 & 0.87 & 1.00 & 1.34 & 0.121 \\
\hline & $\hat{\beta}$. & $R^{2}-$ values & Property & Investor right & Average rate \\
\hline Argentina & 1.12 & 0.16 & 2.73 & 2.16 & 0.165 \\
\hline Brazil & 1.85 & 0.43 & 3.00 & 1.98 & 0.200 \\
\hline Chile & 1.02 & 0.38 & 1.00 & 1.80 & 0.083 \\
\hline China & 1.14 & 0.17 & 4.00 & 1.89 & 0.017 \\
\hline Colombia & 0.52 & 0.05 & 3.36 & 1.41 & 0.179 \\
\hline Czech Republic & 0.63 & 0.09 & 2.00 & 1.55 & 0.205 \\
\hline Egypt & 0.46 & 0.04 & 3.09 & 1.90 & 0.274 \\
\hline
\end{tabular}




\begin{tabular}{|l||c|c|c|c|c|}
\hline India & 0.65 & 0.10 & 3.00 & 1.89 & 0.108 \\
\hline \hline Indonesia & 1.46 & 0.16 & 3.45 & 1.96 & 0.101 \\
\hline \hline Israel & 1.07 & 0.33 & 2.00 & 1.73 & 0.135 \\
\hline Jordan & 0.15 & 0.01 & 2.36 & 1.77 & 0.158 \\
\hline South Korea & 1.59 & 0.24 & 1.27 & 1.53 & 0.149 \\
\hline Malaysia & 0.94 & 0.14 & 2.45 & 1.65 & 0.044 \\
\hline Mexico & 1.44 & 0.44 & 2.91 & 1.55 & 0.175 \\
\hline Morocco & 0.06 & 0.00 & 3.09 & 1.76 & 0.115 \\
\hline Pakistan & 0.41 & 0.02 & 3.18 & 2.43 & 0.141 \\
\hline \hline Peru & 0.69 & 0.12 & 3.45 & 1.96 & 0.156 \\
\hline Philippines* & 1.06 & 0.20 & 2.73 & 1.90 & -0.061 \\
\hline \hline Poland & 1.37 & 0.27 & 2.27 & 1.63 & 0.166 \\
\hline Russia & 2.13 & 0.23 & 3.36 & 2.15 & 0.413 \\
\hline South Africa & 1.11 & 0.35 & 2.91 & 1.59 & 0.114 \\
\hline Thailand & 1.63 & 0.25 & 1.36 & 1.32 & 0.028 \\
\hline \hline Taiwan & 1.10 & 0.26 & 2.09 & 1.71 & 0.022 \\
\hline Turkey & 2.15 & 0.26 & 2.36 & 1.87 & 0.322 \\
\hline \hline Venezuela & 1.01 & 0.09 & 3.45 & 2.27 & 0.172 \\
\hline
\end{tabular}

There appears to be a clear difference between more developed and emerging countries in how much the world rate of return explains national rate of return. The $\mathrm{R}^{2}$-values are in Table 2 higher in more developed countries. The summary statistics in Table 3 confirm that this difference is statistically significant.

Table 3 - Summary statistics for the aggregates of more and less developed countries 1995-2005 (129 months)

\begin{tabular}{|c|c|c|c|c|c|c|c|c|}
\hline & \multicolumn{2}{|c|}{$\mathrm{R}^{2}$ values from $1^{\text {st }}$ pass regression } & \multicolumn{2}{|c|}{$\begin{array}{l}\text { Property-rights } \\
\text { protection }\end{array}$} & \multicolumn{2}{|c|}{$\begin{array}{l}\text { Investor-rights } \\
\text { protection }\end{array}$} & \multicolumn{2}{|c|}{ Rate of return } \\
\hline & $\begin{array}{l}\text { More } \\
\text { developed } \\
\text { economies }\end{array}$ & $\begin{array}{l}\text { Less developed } \\
\text { economies }\end{array}$ & $\begin{array}{l}\text { More } \\
\text { developed } \\
\text { economies }\end{array}$ & $\begin{array}{l}\text { Less } \\
\text { developed } \\
\text { economies }\end{array}$ & $\begin{array}{l}\text { More } \\
\text { developed } \\
\text { economies }\end{array}$ & $\begin{array}{l}\text { Less } \\
\text { developed } \\
\text { economies }\end{array}$ & $\begin{array}{l}\text { More } \\
\text { developed } \\
\text { economies }\end{array}$ & $\begin{array}{l}\text { Less } \\
\text { developed } \\
\text { economies }\end{array}$ \\
\hline Mean & 0.487* & 0.194* & 1.307* & $2.649 *$ & $1.43^{*}$ & 1.81* & 0.124 & 0.149 \\
\hline $\begin{array}{l}\text { Standard } \\
\text { deviation }\end{array}$ & 0.170 & 0.128 & 0.473 & 0.749 & 0.103 & 0.270 & 0.043 & 0.101 \\
\hline Minimum & 0.20 & 0.00 & 1.00 & 1.00 & 1.31 & 1.32 & 0.011 & -0.061 \\
\hline Maximum & 0.87 & 0.44 & 2.36 & 4 & 1.74 & 2.43 & 0.221 & 0.413 \\
\hline Count & 23 & 26 & 23 & 26 & 23 & 26 & 23 & 26 \\
\hline
\end{tabular}


These results can be contrasted with those of Morck et al. (2000), who found considerably lower $\mathrm{R}^{2}$ for individual firms in more developed countries using national indices as market portfolios. Our values correlate negatively with theirs, with statistical significant at one percent. Nevertheless our results are in line theirs. With well-functioning stock-markets and low barriers for international investors opportunities for risk-reduction through international diversification are taken advantage of, leaving only systemic risk of a world market to determine the rate of return.

In contrast, Morck et al. (2000), studying individual stocks, argued that trade individual stocks is to a large extent driven by firm-specific fundamentals, about which more reliable information is easily accessible in more developed countries (see also Jin and Myers, 2006). Firm specific fundamentals are thus more important in the pricing of individual stocks, and co-movement with national indices is lower (i.e., lower $\mathrm{R}^{2}$ in more developed countries, as they found).

The reason why more reliable information is easily accessible in more developed countries is investor protection through secure property rights. This also explains why our $\mathrm{R}^{2}$ values are so low for less developed countries, where more factors than world market portfolio are needed to explain the rate of return, such as property right protection and investor protection.

Like the $\mathrm{R}^{2}$ values, average levels of property right protection and investor-rights protection are higher in more compared to less developed countries. That this is the case was also confirmed by a z-test (see Table 3).

With regard to average rates of return there are no other such systematic differences between the two groups of countries, though there is more variation of the rate of return for less developed countries, as well as in property-rights and investor-rights protection. The negative rate of return for the Philippines is troublesome from a theoretical perspective. According to CAPM it indicates a negative risk-free interest rate, which is not possible. We therefore excluded the Philippines when calculating risk premiums.

Could it be that the composition of the world market portfolio makes it appear that it explain more of the national rates of return in more developed than in less developed countries? Most of Morgan Stanley's world-market portfolio consists of national portfolios from more developed countries, with the USA the largest, $50 \%$. By contrast the weight of all the less developed countries combined is less than $5 \%$.

The fact that the world portfolio consist primarily of stocks from more developed countries could be why $\mathrm{R}^{2}$ values are higher for more developed countries. The correlation of both property rights and investor rights with $R^{2}$ values and with each other, - as expected - is considerably higher of index weights and with $R^{2}$ values (see Table 4). This result suggests that, in countries with insecure property rights and investor rights the market portfolio alone does not explain as much of the national rate of return as in countries with more secure rights. 


\section{Table 4 - Correlation matrix}

\begin{tabular}{|l|r|r|r|r|r|}
\hline & \multicolumn{1}{|c|}{$\mathrm{R}^{2}$} & Property rights & Investor rights & Average returns & Index weights \\
\hline $\mathrm{R}^{2}$ & 1 & & & & \\
\hline Property rights & $-0.658^{*}$ & 1 & & & \\
\hline \hline Investor rights & $-0.627^{*}$ & $0.761^{*}$ & 1 & & \\
\hline \hline Average returns & -0.071 & 0.194 & 0.224 & -0.094 & \\
\hline \hline Index Weights & $0.502^{*}$ & -0.246 & -0.249 & & \\
\hline
\end{tabular}

To test if there is a statistically significant link between the $R^{2}$ values from the first-pass regression and the institutional framework, we first checked if property-right and investor-rights protection can be used as alternative explanatory variables (Table 5a). Then, in order to test the robustness of the results, index weights were included as additional explanatory variables in a second round of regressions (Table $5 b$ ). In all regressions $R^{2}$ values from Table 2 were used as the dependent variable. Since $R^{2}$ is bound been one and zero, we did a logistic transformation of $R^{2}$ yielding

$\vartheta_{i}=\log \left(\frac{R_{i}^{2}}{1-R_{i}^{2}}\right)$

Table $5 a-$ First pass $\mathbf{R}^{2}$ values and protection of property and investor rights

\begin{tabular}{|c|c|c|c|c||}
\hline & \multicolumn{2}{|c|}{ Property-rights protection } & \multicolumn{2}{c|}{ Investor- rights protection } \\
\hline Estimation method & \multicolumn{2}{|c|}{ OLS } & \multicolumn{2}{c|}{ OLS } \\
\hline Dependent variable: $\vartheta_{i}$ & Coefficient & t-value & Coefficient & t-value \\
\hline Property rights $\left(\overline{P R P}_{i}\right)$ & $-0.425^{*}$ & -5.72 & & \\
\hline Investor rights $\left(\overline{I R P}_{i}\right)$ & & & $-1.332^{*}$ & -4.88 \\
\hline \hline Adj. $R^{2}$ & 0.41 & & 0.34 & \\
\hline F-value & 32.7 & & 0.32 & \\
\hline No. of observations & 49 & & 49 & \\
\hline \hline
\end{tabular}


Table $5 b$ - First pass $\mathbf{R}^{2}$-values and protection of property and investor rights, including index weights

\begin{tabular}{|c|c|c|c|c|}
\hline & \multicolumn{2}{|c|}{$\begin{array}{l}\text { Property-rights protection } \\
\text { (PRP) }\end{array}$} & \multicolumn{2}{|c|}{$\begin{array}{l}\text { Investor-rights protection } \\
\text { (IRP) }\end{array}$} \\
\hline & \multicolumn{2}{|c|}{ OLS } & \multicolumn{2}{|c|}{ OLS } \\
\hline Dependent variable: $\vartheta_{i}$ & Coefficient & t-value & Coefficient & $t$-value \\
\hline Property rights $\left(\overline{P R P}_{i}\right)$ & $-0.381 *$ & -5.23 & & \\
\hline Investor rights $(\overline{I R P})$ & & & $-1.171^{*}$ & -4.36 \\
\hline Index weights & $0.024^{* *}$ & 2.43 & $0.025^{* *}$ & 2.41 \\
\hline$R^{2}$ & 0.48 & & 0.41 & \\
\hline $\operatorname{Adj.} R^{2}$ & 0.45 & & 0.39 & \\
\hline F-value & 21.0 & & 16.0 & \\
\hline No. of observations & 49 & & 49 & \\
\hline
\end{tabular}

In countries with weak protection of property and investor rights, the world market returns had less explanatory power (Table 5a). Adding index weights (Table 5b) did not substantially change the results. This suggests that CAPM provide a less adequate tool for understanding asset pricing in less developed countries and financial markets. Therefore we believe that the $R^{2}$ values can be used as proxies for financial development; countries in which CAPM displays a lower explanatory power might be interpreted as less developed financially.

To check for multicollinearity between each of the two indices and the index weights, we calculated the variance inflation factor (VIF). In both cases VIF is close to one, which means that we can rule out multicollinearity. 


\section{Models and results}

In the first step monthly time series data was used to estimate the first-pass regression. In the second-pass regression, as discussed, the index of property-rights or investor-rights protection was included

$\bar{r}_{i}=\alpha_{i}+R P_{m} \times \hat{\beta}_{i}+R P_{P R P} \times \overline{P R P}_{i}+\varepsilon_{i}$

$\bar{r}_{i}=\alpha_{i}+R P_{m} \times \hat{\beta}_{i}+R P_{I R P} \times \overline{\operatorname{IRP}}_{i}+\varepsilon_{i}$

where $\overline{P R P}_{i}$ is the average value of the property-right index and $\overline{I R P}$ is the average value of the investor rights index for country $i$. The results are shown in Table 6 . The coefficient for $P R P$ (property-rights) and IRP (investor-rights) is significant at five percent, indicating the importance of these variables. In both cases less security correlates with a higher risk premium.

Table 6 - Risk-premium factors: property rights and investor rights

\begin{tabular}{|c|c|c|c|c|c|c|}
\hline & \multicolumn{2}{|c|}{$\begin{array}{l}\text { Property-rights protection } \\
\text { (PRP) }\end{array}$} & \multicolumn{2}{|c|}{$\begin{array}{c}\text { Investor-rights protection } \\
\text { (IRP) }\end{array}$} & \multicolumn{2}{|c|}{ Conventional CAPM } \\
\hline Estimation method & \multicolumn{2}{|c|}{ OLS } & \multicolumn{2}{|c|}{ OLS } & \multicolumn{2}{|c|}{ OLS } \\
\hline Depertueri valiante. ${ }_{i}$ & Coefficients & t-values & Coefficients & t-values & Coefficients & $t$-values \\
\hline Intercept $(\alpha)$ & 0.035 & 1.02 & -0.048 & -0.77 & $0.079 *$ & 2.99 \\
\hline Property rights $\left(P R P_{i}\right)$ & $0.021 * *$ & 2.01 & & & & \\
\hline Investor rights $\left(I R P_{i}\right)$ & & & $0.079 * *$ & 2.20 & & \\
\hline$\hat{\beta}$ & $0.062^{*}$ & 2.71 & $0.059 * *$ & 2.59 & $0.060 * *$ & \\
\hline$R^{2}$ & 0.19 & & 0.21 & & 0.12 & \\
\hline Adj. $R^{2}$ & 0.16 & & 0.17 & & 0.10 & \\
\hline F-value & 5.4 & & 5.9 & & 6.4 & \\
\hline No. observations & 48 & & 48 & & 48 & \\
\hline
\end{tabular}


With the conventional CAPM we find an average world risk-free interest rate $(\hat{\alpha})$ of just under 8 percent. However, assuming that the countries with the best values on the property-rights index $(P R P=1)$ and on the investor-protection index $(I R P=1.31)$ have virtually no uncertainty, we find lower risk-free interest rates. Using the best value of the property-rights index, we estimate the risk-free rate to be 5.6 and 5.5 percent using the investor-rights index. The traditional beta is approximately the same whichever - or none - which suggests robustness in the results.

Estimated interest rates including risk premiums for property-right protection and investor-rights protection for all the countries are reported in Table 7. On average there is a three percentage-point difference in rates between less and more developed countries, statistically significant at 5 percent, which can be explained by differences in property-rights protection. The traditional CAPM beta-value does not significantly differ between more and less developed countries. Hence the more developed countries have a much lower risk premium on investments due to systemic risk. Improvement in the institutional framework of less developed countries should be helpful in increasing investments and welfare.

Table 7 - Risk free rate plus risk premiums

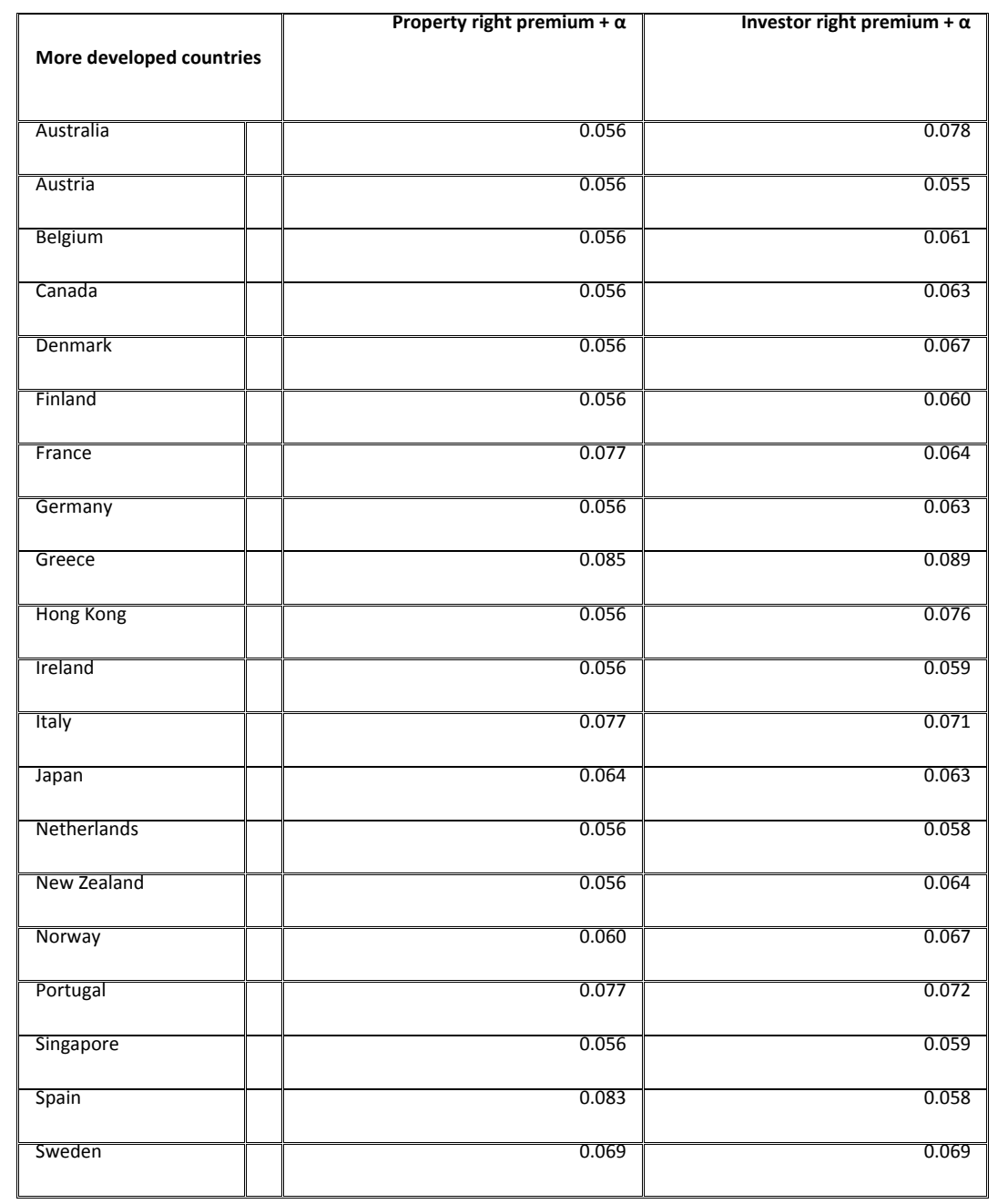




\begin{tabular}{|c|c|c|}
\hline Switzerland & 0.062 & 0.058 \\
\hline United Kingdom & 0.056 & 0.059 \\
\hline United States & 0.056 & 0.058 \\
\hline Averages developed & $0.062^{*}$ & $0.065^{*}$ \\
\hline Less developed countries & & \\
\hline Argentina & 0.092 & 0.123 \\
\hline Brazil & 0.098 & 0.108 \\
\hline Chile & 0.056 & 0.094 \\
\hline China & 0.119 & 0.101 \\
\hline Colombia & 0.106 & 0.063 \\
\hline Czech Republic & 0.077 & 0.074 \\
\hline Egypt & 0.100 & 0.102 \\
\hline Hungary & 0.077 & 0.074 \\
\hline India & 0.098 & 0.101 \\
\hline Indonesia & 0.107 & 0.107 \\
\hline Tsraet & 0.077 & 0.089 \\
\hline Jordan & 0.085 & 0.092 \\
\hline South Korea & 0.062 & 0.073 \\
\hline Malaysia & 0.086 & 0.082 \\
\hline Mexico & 0.096 & 0.074 \\
\hline Morocco & 0.100 & 0.091 \\
\hline Pakistan & 0.102 & 0.144 \\
\hline Peru & 0.107 & 0.107 \\
\hline Poland & 0.083 & 0.081 \\
\hline Russia & 0.106 & 0.122 \\
\hline South Africa & 0.096 & 0.078 \\
\hline Thailand & 0.064 & 0.056 \\
\hline Taiwan & 0.079 & 0.087 \\
\hline Turkey & 0.085 & 0.100 \\
\hline Venezuela & 0.107 & 0.131 \\
\hline Average less developed & $0.091^{*}$ & $0.095^{*}$ \\
\hline
\end{tabular}

For the conventional CAPM, Ramsey's regression specification-error test (RESET) indicates a problem of omitted variables (F-test 8.23), which also supports the inclusion of further explanatory variables. This is consistent with the fact that the $R^{2}$ and adjusted $R^{2}$ values almost double with the inclusion of either of the two indexes. 


\section{Summary and conclusions}

How to account for institutional risk such as insecure property-rights or investor-rights has not received much attention in models of risk and return in the finance literature. In this paper we estimate how the cost of capital is influenced by the quality of property-rights and investor-rights protection. We find that the cost of capital increase significantly in countries where property rights and investor rights enjoy less protection.

But Morck et al. (2000) explain why $\mathrm{R}^{2} \mathrm{~s}$ in first-pass regressions in the capital asset pricing model (CAPM) are so low for the U.S. compared to less developed countries. Their explanation is that legal uncertainty (in terms of property-rights and investor-rights protection) is lower in the U.S. which makes it possible for analysts to get access to proprietary firm-specific information, which then influence stock prices more in the U.S. than in less developed countries. As a consequence, CAPM explains less.

We also find that legal uncertainty in quality of is important in explaining within country differences in predictive power of CAPM. But, in contrast to Morck et al., we used world market portfolio as explanatory variable and studied the return on national portfolios. With such an approach it was possible to see how risk premiums (cost of capital) in national stock markets are influenced by property-rights and investor-rights.

$R^{2} s$ in our case are lower in less than in more developed countries, which can be explained by legal uncertainty in the form of weak property-rights and investor-rights. When property-rights or investor-rights protection were added, the predictive power of CAPM increases substantially, and higher risk premiums were found for countries with weaker protection. 
Acknowledgements: Financial support from the Marianne and Marcus Wallenberg Foundation is gratefully acknowledged. Furthermore we acknowledge valuable comments provided by Åke E. Andersson, Niclas Berggren, Sameeksha Desai, Dennis C. Mueller, Göran Skogh, and participants at conferences of the European Association of Law and Economics.

\section{References}

Alchian, A. A., \& Demsetz, H. (1972). Production, information costs, and economic organization. American Economic Review, 62(5), 777-795.

Barrow, R. J., (1991). Economic growth in a cross section of countries. Quarterly Journal of Economics, 106(2), 407-443.

Black, F., Jensen, M. C. \& Scholes, M. (1972). The capital asset pricing model: Some empirical tests. In M.C. Jensen (Ed.), Studies in the Theory of Capital Markets, New York: Praeger.

Claessens, S. \& Laeven, L. (2003). Financial development, property rights, and growth. Journal of Finance, 58(6):2401-2463.

Coase, R. H. (1960). The problem of social cost. Journal of Law and Economics, 3: 1-44.

Demsetz, H. (1964). "The exchange and enforcement of property rights," Journal of Law and Economics, 7, 11-26

Douglas, G. (1968). Risk in the equity markets: An empirical appraisal of market efficiency, Ann Arbor, Mich.: University Microfilms, Inc.

de Soto, H. (2000). The mystery of capital - Why capitalism triumphs in the west and fails everywhere else, Basic Books, New York.

Elton, E. J. \& Gruber, M. J. (1995). Modern portfolio theory and investment analysis, $5^{\text {th }}$ ed., New York: John Wiley \& Sons, Inc.

Faure, M. \& Skogh, G. (2003). The Economic analysis of environmental policy and law: An introduction, Cheltenham: Edgar Elgar Publishing Ltd. 
Gugler, K., Mueller, D. C. \& Yurtoglu, B. B. (2004). Corporate governance and return on investment. Journal of Law and Economics, 47(2), 589-633.

Jin, L., \& Myers, S. C. (2006). $\mathrm{R}^{2}$ around the world: New theory and new tests. Journal of Financial Economics, 79(2), 257-292.

Johnson, S., McMillan, J. \& Woodruff, C. (2002). Property rights and finance. American Economic Review, 92(5), 1335-1356.

Kasper, W. \& Streit, M. E. (1998). Institutional economics - Social order and public policy. Cheltenham: Edgar Elgar Publishing Ltd.

La Porta, R., Lopez-De_Silanes, F., Shleifer, A. \& Vishny, R. W. (1997). Legal determinants of external finance. Journal of Finance, 52(3), 1131-1150.

Merton, R. C. (1973). An intertemporal capital asset pricing model. Econometrica, 41(5), 867-887.

Morck, R., Yeung, B. \& Yu, W. (2000). The information content of stock markets: Why do emerging markets have synchronous stock price movements. Journal of Financial Economics, 58(1), 215-260.

Mueller, D. C. (2003). The Corporation - Investments, mergers and growth. London: Routledge.

North, D. C. (1990). Institutions, institutional change and economic performance. Cambridge and New York: Cambridge University Press.

North, D. C. (1981). Structure and Change in Economic History. New York: Norton.

Roll, R. (1977). A critique of the asset pricing theory's tests: Part I: On past and potential testability of the theory. Journal of Financial Economics, 4(2), 129-176.

Sharpe, W. F. \& Cooper, G. M. (1972). Risk-return class of New York stock exchange common stocks, 19311967. Financial Analysts Journal, 28(2), 46-52.

Williamson, O.E. (2000). The new institutional economics: Taking stock, looking ahead. Journal of Economic Literature, 38(3), 596-613. 


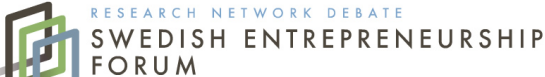
4 FORUM

Working Paper 2012:12 


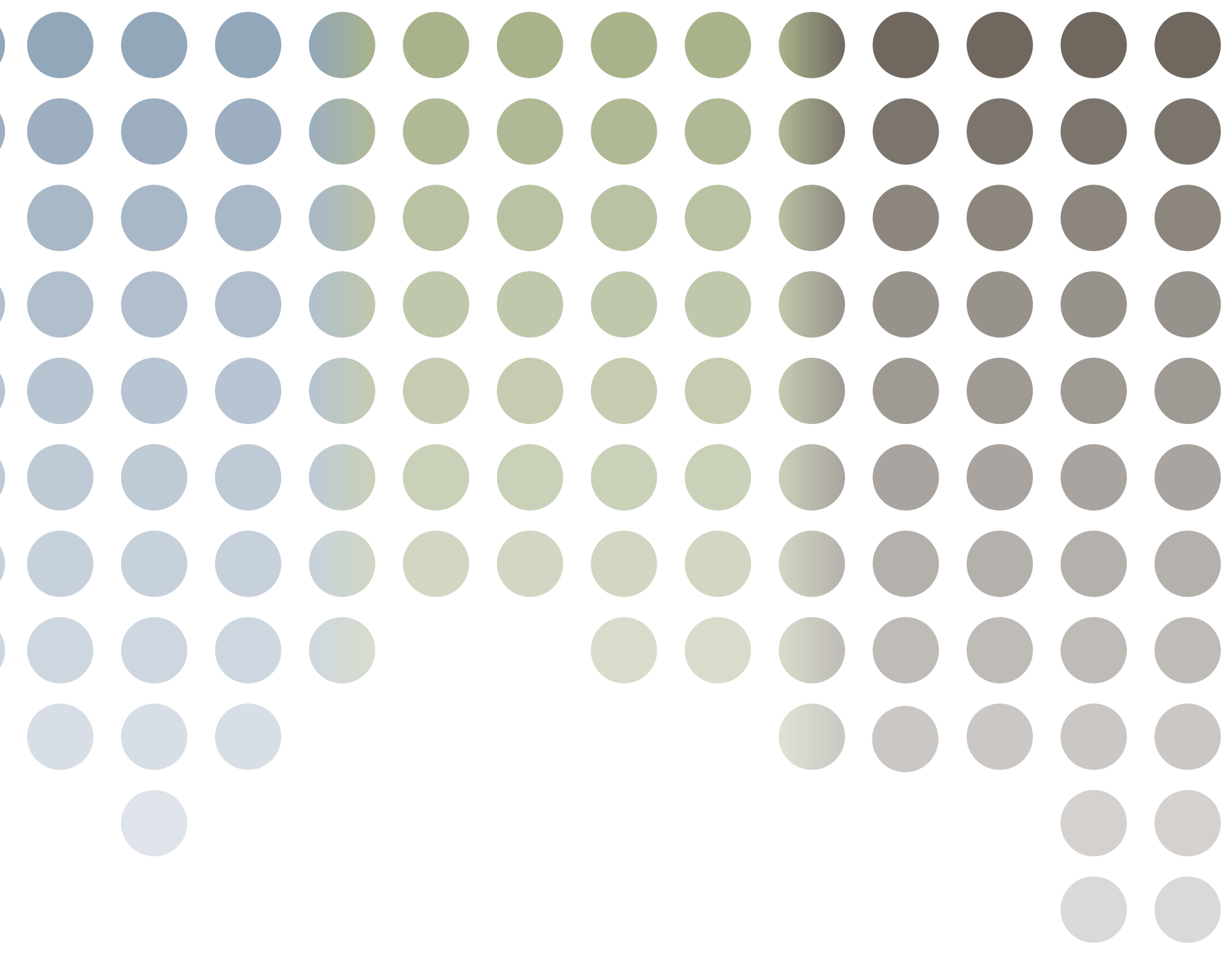

